\title{
Education practices: research-action with nurses of Family Health Strategy
}

\author{
Práticas educativas: pesquisa-ação com enfermeiros da Estratégia de Saúde da Família \\ Prácticas educativas: investigación-acción con enfermeros de la Estrategia de Salud de la Familia
}

\begin{abstract}
Carlos Frank Viga Ramos',", Raimunda da Costa Araruna", Charlene Maria Ferreira de Lima ${ }^{1,11}$, Carmen Lúcia Albuquerque de Santana', Luiza Hiromi Tanaka'

'Universidade Federal de São Paulo, Paulista Nursing School. São Paulo, Brazil.

"Universidade Federal do Acre. Rio Branco, Acre, Brazil.
\end{abstract}

How to cite this article:

Ramos CFV, Araruna RC, Lima CMF, Santana CLA, Tanaka LH. Education practices: research-action with nurses of Family Health Strategy. Rev Bras Enferm [Internet]. 2018;71(3):1144-51. DOI: http://dx.doi.org/10.1590/0034-7167-2017-0284

Submission: 10-24-2016 Approval: 08-29-2017

\begin{abstract}
Objective: to identify the factors that determine the implementation of educational practices of health promotion and to construct proposals to implement the educational actions of the nurses of the Family Health Units (FHU). Method: researchaction in which individual interviews and focus group were conducted, with 17 nurses from 12 FHU in the city of Cruzeiro do Sul, Acre state, Brazil. The results were organized by the thematic analysis method. Results: the thematic units emerged from the analysis: dichotomy between knowledge and doing in the production of care and health; the nurse's qualification for educational practices; and conditions favorable to health education practices. Conclusion: the thematic analysis showed that the educational practice is hampered by the high demand for care in the unit, lack of physical structure and professional qualification for health education. In the action phase, nurses and local managers agreed on actions to improve the quality of educational practices.

Descriptors: Collective Health; Family Health; Health Education; Community Health Nursing; Public Health Nursing.
\end{abstract}

\section{RESUMO}

Objetivos: identificar os fatores que determinam a implementação de práticas educativas de promoção da saúde e construir propostas para efetivar as ações educativas dos enfermeiros das Unidades de Saúde da Família (USF). Método: pesquisa-ação em que foram realizadas entrevistas individuais e grupo focal, com 17 enfermeiros de 12 USFs do município de Cruzeiro do Sul, Acre, Brasil. Os resultados foram organizados pelo método de análise temática. Resultados: emergiram da análise as unidades temáticas: dicotomia entre o saber e o fazer na produção do cuidado e saúde; a qualificação do enfermeiro para as práticas educacionais; e condições favoráveis às práticas de educação em saúde. Conclusão: a análise temática mostrou que a prática educativa é dificultada pela alta demanda de atendimento na unidade, falta de estrutura física e qualificação profissional para a educação em saúde. Na fase ação, os enfermeiros e gestores locais pactuaram ações para melhorar a qualidade das práticas educativas.

Descritores: Saúde Coletiva; Saúde da Família; Educação em Saúde; Enfermagem em Saúde Comunitária; Enfermagem em Saúde Pública.

\section{RESUMEN}

Objetivo: identificar los factores que determinan la implementación de prácticas educativas de promoción de la salud y diseñar propuestas para efectuar las acciones educativas de los enfermeros de las Unidades de Salud de la Familia (USF). Método: investigación-acciones en las cuales se realizaron entrevistas individuales y grupo focal, con 17 enfermeros de 12 USFs de la ciudad Cruzeiro do Sul, Acre, Brasil. Los resultados fueron organizados según el método de análisis temático. Resultados: han aparecido del análisis las unidades temáticas: dicotomía entre el saber y el hacer en la producción del cuidado y salud; la cualificación del enfermero para las prácticas educativas; y condiciones favorables a las prácticas de educación en salud. Conclusión: el análisis temático mostró que la práctica educativa es dificultada por la alta demanda de atención en la unidad, falta de estructura física y calificación profesional para la educación en salud. En la fase de acción, los enfermeros y gestores locales pactaron acciones para mejorar la calidad de las prácticas educativas.

Descriptores: Salud Colectiva; Salud de la Familia; Educación en Salud; Enfermería en Salud Comunitaria; Enfermería en Salud Pública. 


\section{INTRODUCTION}

Health education is a field of knowledge and practice in the area of health care that seeks to promote health and prevent diseases in the various levels of complexity of the healthdisease process. In this way, health education is understood as the process of theoretical-practical learning that has the purpose of integrating diverse knowledge, such as scientific, popular and common sense, enabling the individuals involved to develop a critical vision about the production of health care ${ }^{(1)}$.

In this view, the educational practice in the Family Health Strategy (FHS) becomes an extremely important activity, since it allows the intermediation of health professionals with the community, offering subsidies for the adoption of new habits and behaviors of health, in the prevention of aggravations and also as means for the strengthening, as a citizen ${ }^{(2-5)}$.

As a result, educational actions would include a "new perspective on health promotion", aimed at achieving a "new health-disease process", so that healthy people can take better care of their health, including more health promotion practices in their daily life. This proposed perspective seeks to break the biomedical paradigm, as well as to care of healthy people in their process of living ${ }^{(4)}$.

Contrasting the ideal perception of educational practices, studies show that professionals working in the FHS end up developing educational activities focused on the disease ${ }^{(5-6)}$. In another research, it is demonstrated that nurses understand the educational practice as guiding the health-disease process, considering it of fundamental importance for disease prevention and health promotion. However, when they talk about their actions, they reproduce another form of assistance, based on the transfer of information and emphasis on technical and non-popular knowledge, not contributing to the exchange of knowledge ${ }^{(7)}$.

The interest in this subject arose from the professional experience as a nurse of the FHS, and later, as a teacher of the Bachelor of Nursing course, following the health practices developed by the students in the network of basic health care, in Family Health Units.

In this experience, it was notorious to verify the performance of the nurse in the consolidation and improvement of the FHT as an articulator and integrator with the population for health promotion and prevention of injuries, however, the accumulation of bureaucratic and assistance responsibilities, educational practices, often taxation or verticalized, leads the nurse to fail to perform them in order to meet the real health needs. Thus, it seems to be necessary to develop studies that discuss with the nurses' collective about the practice of health education in the health-disease process, in order to understand the reality of daily work and contribute to better enable this action.

\section{OBJECTIVE}

Identify the factors that influence the implementation of educational practices for health promotion.

Construct proposals to carry out the educational actions with the nurses' collective of the Family Health Units (FHU) and the managers of the Family Health Strategy.

\section{METHOD}

\section{Ethical aspects}

After the approval of the Research Ethics Committee of the Universidade Federal de São Paulo, the participants received the guidelines and signed the Informed Consent Form.

\section{Type of study}

It was delineated the research in the qualitative approach, developed in the action research modality ${ }^{(8)}$, using the thematic content analysis method for data treatment ${ }^{(9)}$.

\section{Methodological procedures}

\section{Study scenario}

This study was carried out in the city of Cruzeiro do Sul (AC) - Northern Region of Brazil, in the Family Health Units (FHU), a field for primary health care activities of the Universidade Federal do Acre (UFAC).

\section{Data source}

Seventeen nurses from $12 \mathrm{FHU}$ from urban and rural areas participated in the study. The nurses were chosen intentionally because they carried out the process of health education in the FHU.

\section{Collection and organization of data}

It was developed in two phases, exploratory and action. The contact with the participants happened by means of invitation letter, and the meetings, scheduled according to the date and place of convenience of the participants. Data collection took place from December 2012 to July 2013.

In the exploratory phase the data were collected through individual interviews, guided by a semi-structured script to understand the meaning of health education in the healthdisease process and to verify factors that influence the health education practices performed by nurses in FHU.

The second phase, the action, the data collection took place through three meetings of Focal Group (FG) that were recorded in audio and lasted 1 hour and 30 minutes each. The discussions of the meetings were guided by triggering questions, built according to the results of the analysis of the data collected in the first phase. At the last meeting, proposals for implementation of health education actions by nurses at FHU were built.

After the analysis of the data, another action was taken, the meeting with the nurses of the urban zone and some of the rural area, the coordinators of the FHS and Health Education, the Municipal Secretary of Health and the coordinator of the nursing course of UFAC to present the proposals made by FHU nurses and agree on actions to improve the quality of health education practices, collaborating in this construction to carry out educational actions.

\section{Data analysis}

The data of the interviews and the focus group were transcribed and analyzed according to the thematic content analysis method according to the phases of pre-analysis, material 
exploration, treatment of the results that emerged three thematic units, and interpretation, in which the discussion took place of these units, correlating the themes with the theoretical reference on the subject, where the contents were transformed into meaningful and valid information ${ }^{(9)}$.

\section{RESULTS}

Of the participants, one was male and sixteen female, the predominant age group was 27 to 44 years old, one with specialization. The participants' professional time ranged from two to ten years, nine of them had exclusive professional dedication and the others had another employment relationship.

Thematic unit 1 - Dichotomy between the knowing and doing in the production of care and health (US1- The cultural issue in health and US2- Excessive demand for care and few professionals); Thematic unit 2 - The nurse's qualification for educational practices (US1- The need for qualification and US2- Dissatisfaction with the results of lectures and group practice and the need for current methods of learning); Thematic unit 3 - Favorable conditions to health education practices.

\section{Thematic unit 1- Dichotomy between knowing and doing} in the production of care and health

In this Thematic Unit, it was possible to understand the perceptions of the participants of the Focus Group before the dichotomy, knowing and doing, in the production of health care.

\section{US1- The cultural issue in health}

Participants expressed difficulty in developing health actions based on the FHS principles, where they are mostly focused on coping with the already established disease process, being influenced by the cultural aspect of the community that attributes greater credibility to individualized health care:

The theory is very beautiful, but when going to practice we are faced with the cultural issue and the nurse finishes getting settled and only practices the dressing forgetting the preventive. (Jasmine, GF1)

I believe that the system implies in a negative way in our service because when we try to do actions based on principles established by the FHS, we are faced with difficulties, what the manager and the population want is productivity within the unit. (Hydrangea, GF1)

The community does not seek the primary care service without complaints, it maintains a relationship with FHU based on the logic of the biomedical model, maintaining the focus on clinical care. Although the program's services are related to primary and secondary prevention, the production of health care is often due to the central motive that led the user to the FHU, thus disregarding the conditioning factors and the aspects related to prevention:

Unfortunately it is not in the interest of the community to learn, either because it is boring, or because it will not put into practice, of course it is not $100 \%$ of people, there are people who go and care, who participate, who do what we say, but you can be sure that it is the minority minority. (Lily, GF3)

The activities with the groups are difficult because they only come if you have a breakfast or something else. (Sunflower, GF2)

\section{US2- Excessive demand for care and few professionals}

The nurse has an integrative and expanded vision about the needs of the actions in the FHS, but can not implement them due to the logic of productivity in the care set up in the units, due to the great concentration of nursing consultations, especially prenatal care. Added to this situation, they feel pressured by the coordinators of the FHU and even the users themselves, so that they stay in the unit conducting nursing consultations. This fact demonstrated in the speech:

The system ends up leaving the theory aside, for example, in the unit where I work, I even try to do health education activity, but the system does not allow because the demand is so great that we end up running out of time, ends up getting an overhead of prenatal and PCCU. (Jasmine, GF1)

\section{Thematic unit 2- The nurse's qualification for educational practices}

This thematic unit is represented by the nurses' perceptions about the weaknesses in relation to the knowledge of $\mathrm{FHU}$ nurses to perform actions with effective strategies for daily health education.

\section{US1- The need for qualification}

The nurses revealed difficulties in carrying out health education actions, since they were trained for clinical practice, not educator. They expressed their longing for the need for professional qualification, since they showed that the absence of specific knowledge of how to act in the FHS creates major obstacles in guaranteeing the production of health care.

With the qualification, nurses can develop health education actions permanently, empowering themselves with the community. As demonstrated in the statements below:

Continuing education or professional qualification would do a lot for us because we would learn the right way to work with the community and make them understand what we want to do and make health education more interesting, even for children, by using puppets in theaters and various ideas, other than that usual thing like the lectures. (Gerbera, GF2)

Now with a specialization course that I've been pursuing on my own, I'm realizing how little I was doing within the FHP (Sunflower, GF2)

\section{US2- Dissatisfaction with the results of lectures and group practice and the need for current methods of learning}

The absence of a pedagogical preparation to carry out educational actions is another factor that contributes substantially to the quality of the educational practices, since it has reported great limitations of the method that uses, like the lectures, since they always need to speak the same subject for the same 
public and this becomes tiresome for both professionals and users.

The lecture is the last resort, not the first one because there is already this issue of the lecture to be boring and tiring, then, we always think of something else, a dance, a theater. (Sunflower, GF3)

The choice of educational strategy is important. In addition, establishing the link between nurses and the community, which is indispensable in educational practice, is achieved through actions aimed at the real needs of the community, thus, the relationship of professionals with users would be strengthened through increased trust and the establishment of links that are so important to ensure comprehensive and resolute health care. Let's see what the participants say:

It is important to know what the community wants to know, not what we think to be the best. (Gerbera, GF1)

There is no use in imposing our knowledge and despise knowledge of the community. (Lily, GF1)

\section{Thematic unit 3- Favorable conditions to health education practices}

The nurses list points to be developed with the purpose of improving the adherence of users and staff to the problems faced and possible interventions to improve the health education actions performed by nurses in FHU.

US1- Awareness of professionals, spaces to develop educational practices, accumulation of functions, professional valuation and autonomy

In order to implement health education activities in the daily routine of nurses' practices, it is essential to raise the awareness of professionals to establish a health care closer to the community, and consequently, more resilient to health promotion and prevention:

What has to be done is to start doing, issue of professional awareness, it is an issue that in the course of time we have been really accommodated and we have to start doing. (Sunflower, GF1)

The involvement of the multiprofessional team in the production, planning and implementation of educational practices is necessary in view of the fact that health care is the responsibility of all members, not restricted to nurses. The involvement of the members of the multiprofessional team must occur in such a way that they can jointly rethink their practices and share the attributions common to all professionals:

It needs to have the collaboration of all the professionals of the team to develop the actions of promotion, because only the nurse does not give account. (Daisy, GF1)

Closer relations with the community are fundamental to developing educational practice outside and within the unit, through the use of alternative spaces such as churches, community centers, and the creation of groups such as pregnant women, the elderly, etc. These educational actions should work on a permanent basis, and with innovative educational practices that can establish a bond with the community and ensure that these activities actually produce an improvement in the quality of life of the users:

I think it has to do continuous education with the population, make groups, monthly for both men and women, adolescents and children, would work. (Violet, GF1)

Health education should not be carried out for 2 to 3 months, but on a routine basis, this lack of routine generates a lack of credibility with the population. (Gerbera, GF1)

The restoration of home visits on a regular basis in the daily routine of their practices through the administration of time, organization of work activities and planning of health education actions, becomes indispensable. Thus, the excessive demand in the unit may decrease, because if the nurse is closer to the community for the development of health care actions more effective for the users' reality:

I believe that initially we have to have time available to carry out health education. (Hydrangea, GF1)

Community participation, team planning in actions is important to have a good result, we need partnerships. (Daisy, GF3)

One of the major obstacles hindering the development of health education activities by nurses at the FHS is the absence of a management plan for the professionals that are included in primary care, especially nurses. However, as a proposal to solve this obstacle, it would be the construction of an intersectoral articulation between the municipality and the educational institutions of the region, which in this case would be only the campus of the Universidade Federal do Acre, where there may be an articulation to try to make feasible a partnership which would guarantee a specialization course aimed at the FHS and thus ease this lack:

I think it would be very good to do these improvement courses and we could even think of partnerships like UFAC, because the municipality has no structure and thus improve health education practices in the units. (Gerbera, GF2)

A proposal highlighted by nurses to improve health education spaces would be to enable the Municipal Health Department to provide appropriate spaces, as the absence of an appropriate place leads nurses to do these activities in the corridors of the unit and the nursing room, without comfort to the users.

Three health units undergoing structural reform were observed in the data collection; however, nurses reported that at no point were they consulted about possible adjustments to be made at the unit, such as the construction of a space for educational practices. 
The participation of health professionals in the elaboration of the reform project and even the construction of the units becomes of extreme necessity, since they will be acting on a daily basis in the FHU and, therefore, they know of the limitations existing in the physical space to be reformed and built:

The spaces to carry out the educational actions in the community is an alternative, being essential to have an appropriate place also in the unit, the ideal would be to have a fixed space to develop educational activity with the community. (Gerbera, GF2)

When the manager is to enlarge or remodel the unit consult the nurse and the staff who works on the premises. Take into account the demands for professionals. (Sunflower, GF2)

Another weakness recognized by the participants that are detrimental to health education activities is the great turnover of the nursing professionals in the family health teams, constant reallocations, and the ideal would be to fix the professionals in the FHU and implement a policy of qualification and professional appreciation, the concrete result of this would be qualified nurses, motivated and more familiar with the problems experienced by the community:

A negative point that influences health education and should be reviewed is the fact that nurses are rotating in the units, the health department makes many changes of the professionals. (Gerbera, GF2)

The professional has to raise awareness about what is important, of these actions and also claim who is ahead of the management of the secretariat, claim resources for these actions, claim better wages to motivate. (Sunflower, GF3)

In this context, poor working conditions, such as inappropriate physical space for educational practice, lack of didactic material, as well as financial valuation of the professional, substantially interfere with the quality of educational actions developed in the daily life of the units. Faced with these obstacles, the nurses emphasize proactivity in order to overcome the obstacles, seeking a greater commitment on the part of the managers in order to consolidate a health education in the FHU.

Therefore, in a strategic meeting between these actors, management committed itself to solve the structural problems listed, as well as to seek partnerships with public institutions of education with the purpose of qualifying the nurses of FHU. Already, these have pledged to implement, with greater intensity, educational practices in the production of health care.

\section{DISCUSSION}

In the Brazilian health services, an assistance model predominates that privileges the curative actions and focuses on the medical care, according to a strictly biological vision of the health-disease process, that conditions the educational practice to actions that aim to modify practices of the individuals considered inadequate by the professionals, through the prescription of treatments, behaviors and changes in behavior ${ }^{(10)}$.
Participants Jasmine and Hydrangea expressed that these situations arise through the accommodation of nurses, also due to problems of health productivity system, where the managers take ownership and the population is conditioned, creating a culture in health. Naturally, they result in low population linkages to health services and frustration of health professionals, who often blame the population for acting in accordance with the healthcare model imposed by the health system ${ }^{(10)}$.

The conduct of health actions based on medicalization reinforces the idea of health with a greater quantity of medications, consultations and examinations to the detriment of the health problems of the population related to their life situations ${ }^{(11)}$.

In this assistance model, the educational activities called participatory, especially in the formation of groups, the educational action takes place through lectures or lectures, practically lacking collective space for dialogue and other manifestations that are not specific doubts to be answered by professionals or information, which contributes little to emancipatory education ${ }^{(10)}$. Participants, Lily and Sunflower expressed about the lack of interest of FHU users in educational actions, especially those of group, where they were taught in the form of class.

The view of health education in the FHS should be broadened considering the community, especially the family in the integral form and in its social space, that is, the person should be approached in its socioeconomic and cultural context, and recognized as a social bearer subject of autonomy, recognizing that it is in the family that interactions and conflicts occur that directly influence people's health ${ }^{(5)}$.

In this way, health professionals, especially those inserted in basic care, must internalize the principles established in the FHT, which aim at the integral care of the family within its assigned territory. Health education becomes an indispensable tool to produce significant changes in the way of conducting the health care process ${ }^{(12)}$.

There is an abyss between nurses' theory and practice, since the participants were aware of the actions they should take with the community, promoting health and preventing diseases through home visits and creating strategies of proximity to the population. With the limited attendance in the unit, they end up being hostages of actors inserted in the process of health care with a distorted and limited vision on the FHT.

The process of health construction requires actions that enable the autonomy and inclusion of people. And the educational actions developed by the nurse in the FHS need adaptations to meet the social demands of the health service assisted by these professionals. In these actions, nurses must be careful not to fail to meet the real health needs of the users, and thus not lead to a suppressed demand in health care ${ }^{(13)}$. The lack of personnel and the excess of daily activities highlighted by the participants are problems that are part of the history of the work in nursing and that justify the priority of assistance demands in favor of the educational ones.

The academic training and qualification of the professionals about the Unified Health System (SUS) and FHS interfere in the practice of health education according to the significant approach of the participants of this research. They often receive an education based on "light/hard and hard technologies", valuing 
scientificity and technicality ${ }^{(14)}$. Added to a "banking" learning, where the establishment of the relationship between teacher and student or professional and user becomes hierarchical, disregarding popular knowledge, without the inclusion of users and with little impact on the daily life of communities, based on the values established by the model biomedical, which little propitiates the constitution of professionals and users as subjects of health $\operatorname{care}^{(2,5-7,10,13-15)}$. The participant Sunflower, the only one who attended the specialization, awakened when she was not aware of the nurse's role in the FHS, including educational actions with the community.

The health education model, still in practice in the country's higher education institutions, reinforces the profile of professionals trained in specialties, to the detriment of the majority of the population's needs ${ }^{(11)}$.

Even with this limitation, the professionals who work in the FHT have a differentiated view on the production of health care, and, therefore, seek greater empowerment on the primary care themes.

Health education, therefore, becomes a strategy for nurses to ensure the maintenance of individual and collective health, with critical awareness, and allow the exercise of citizenship, effecting personal and social changes, formed ethical subjects capable of making society more just, humane and supportive $\mathrm{e}^{(11)}$.

In order to do so, the nurse-educator confers on his pedagogical action a new dimension, allowing him to regard the learner not as an object, but to recognize him as a person, and in their interactions, they will move to a dialogical moment ${ }^{(3,7,16)}$.

The goal of dialogic education is not to inform health, but to transform existing knowledge, addressed by participants Gerbera and Lily. The educational practice, in this perspective, aims at the development of the autonomy and the responsibility of the individuals in the care with the health, but no longer by the imposition of a technical-scientific knowledge held by the health professional, but by the development of the understanding of the health situation ${ }^{(10)}$.

This makes it necessary to internalize the conceptions and practices of health education in FHS by nurses ${ }^{(3)}$ and other health professionals, to be acquired through courses, but:

[...]nowadays, there is an amount of financial resources spent by governments - federal, state and municipal - in training, through the purchase of training courses, with universities or the like, that we know are not able to handle the intervention processes on the day to day of doing health. The impacts of these forms of learning are very restricted ${ }^{(17)}$.

Therefore, it is also necessary to think about the best strategy to train these professionals in order to achieve the objectives of being health promoters in the FHT, as presented by the participants.

At the place where the study was developed, the participants' speeches, Gerbera, Hydrangea and Sunflower, stand out about the physical and emotional exhaustion in which the majority is due to the 40 hours a week during the day at the FHS and 30 night hours in hospitals, which compromises work performance. It is common for some nurses to fail at the FHU to attend a hospital shift, and the community is obliged to go to another unit in search of nursing care, generating an overload in the nursing care of the other FHU, in addition to the nurses' rotation, justifying little educational activity. These issues are discussed with the municipal FHS manager and the nurses from the urban and rural areas who will study a way of contemplating better working conditions.

In view of the proposals pointed out by the participants to qualify the educational practices in the FHT, it directs two educational dimensions: one regarding the training of nurses and the other, the search for education strategies promoting the dialogue between worker and population.

The perspective of strategies to subsidize educational actions in the work of nurses in the PSF points to the use of communication in home visits and nursing consultations and educational workshops, in contrast to the traditional approach to health education and the challenges posed in the current scenario health. Workshops with the aim of systematizing an educational intervention of an emancipatory and critical nature, using elements of pedagogical psychodrama, based on the understanding that the health-disease process is due to the way society is organized and that different social segments present different epidemiological profiles ${ }^{(10)}$.

A recent study with Australian nurses has shown the need to schedule workshops to enable them to problematize the issues and to dialogue as 8-hour pairs with a flexible approach to raising awareness and improving nurses' skills in primary health care, focused on health promotion. Participants reported high levels of trust and knowledge in health promotion through workshops ${ }^{(18)}$.

Another workshop held with the professionals of five family health teams ensured collective spaces for the construction of therapeutic projects, based on a user-centered ethicalpolitical engagement. Health education, in the beginning was approached as frustrating by the professionals, however, this one lost centrality during the workshops. Such a change was not limited to a strictly pedagogical dimension, but the teams started to have a valid interlocutor with whom one has to settle, before even placing it as an object of an educational process ${ }^{(19)}$.

\section{Study limitations}

This study had as a limitation not having included the other professionals of the basic team of the Family Health Strategy.

\section{Contributions for the Nursing, Health and Public Policy areas}

This was the first study on this theme held in a participatory manner with nurses in the northern region. Published articles on health education at FHS in Brazil, highlighted in the references of this article, have shown that other Brazilian regions present similar problems found in this study. This demonstrates the need to rethink and evaluate the care and educational model proposed by the Unified Health System (SUS) in the FHS to the teams and, especially, to the nurses, seriously, since it involves public resources paid for the implementation of these practices and the norms that guide them in order to promote health through educational means, with no expected results.

The research points out the need for a collective movement of nurses to discuss educational practices in health, which this study provided, seeking solutions with strategic actors, in 
order to strengthen their role in the actions of local health education, with a view to regional and national levels.

\section{FINAL CONSIDERATIONS}

The factors that influence the implementation of educational practices for the promotion of health in the FHS are the excessive demand for consultations, the population prioritize the attendance to the disease, the management value the productivity and lack of autonomy of the nurse in the conduction of the real need of the population, lack of adequate structure, lack of personnel, work overload and, above all, the absence of professional qualification focused on the Unified Health System (SUS), FHT and health education.
The effectiveness of educational practices occurs in a hierarchical, traditional way, where the appreciation of the knowledge of the population is little considered. Dialogic and participatory processes were not fully developed and it was evidenced that the nurses of the FHS are dissatisfied with the results achieved with the educational practices they develop.

Regarding the proposals, they long for their qualification by means of improvement courses, post-graduation lato sensu at the Public University that was agreed with the representative of UFAC and improvement of the working conditions, agreed with the managers of the FHS of the municipality of Cruzeiro do Sul, together with the FHU nurses. Participating and nonparticipating nurses present at the meeting with the managers corroborated the results of this study.

\section{REFERENCES}

1. Reis CD. Educação em Saúde: aspectos históricos e conceituais. In: Gazzinelli MF, Reis CD, Marques RC, (Org.). Educação em Saúde: teoria, método e imaginação. Belo Horizonte: UFMG; 2006.

2. Alves VS. Um modelo de educação em saúde para o Programa Saúde da Família: pela integralidade da atenção e reorientação do modelo assistencial. Interface Comun Saúde Educ. 2005;9(16):39-52.

3. Roecker S, Marcon SS. Educação em saúde na estratégia saúde da família: o significado e a práxis dos enfermeiros. Esc Anna Nery Rev Enferm [Internet]. 2011[cited 2016 Sep 15];15(4):701-9. Available from: http://www.scielo.br/pdf/ean/v15n4/a07v15n4.pdf

4. Salci MA, Maceno P, Rozza SG, Silva DMGV da, Boehs AE, Heidemann ITSB. Educação em saúde e suas perspectivas teóricas: algumas reflexões. Texto Contexto Enferm [Internet]. 2013[cited 2016 Sep 15];22(1):224-30. Available from: http://www.scielo. $\mathrm{br} / \mathrm{pdf} / \mathrm{tce} / \mathrm{v} 22 \mathrm{n} 1 / 27 . \mathrm{pdf}$

5. Pereira MDM, Pestana T, Maria E, Vaz C, Collet N. Conceptions and Practices of Professional Family Health Strategy for Health Education. Ciênc Saúde Colet [Internet]. 2014[cited 2016 Sep 15];23(1):167-75. Available from: http://www.scielo.br/pdf/tce/ v23n1/0104-0707-tce-23-01-00167.pdf

6. Alves GG, Aerts D. As práticas educativas em saúde e a Estratégia Saúde da Família. Ciênc Saúde Colet [Internet]. 2011 [cited 2016 Sep 15];16(1):319-25. Available from: http://www.scielo.br/pdf/csc/v16n1/v16n1a34.pdf

7. Cervera DPP, Parreira BDM, Goulart BF. Educação em saúde: percepção dos enfermeiros da atenção básica em Uberada (MG). Ciênc Saúde Colet [Internet]. 2011[cited 2016 Sep 15];30(7):1547-54. Available from: http://www.scielo.br/pdf/csc/v16s1/ a90v16s1.pdf

8. Thiollent M. Metodologia da pesquisa-ação. 18th ed. São Paulo: Cortez; 2011.

9. Minayo MCS. O desafio do conhecimento: pesquisa qualitativa em saúde. 12th ed. São Paulo: HUCITEC; 2012.

10. Chiesa A, Veríssimo M. A educação em saúde na prática do PSF. IDS [Internet]. 2001[cited 2016 Sep 15];34-42. Available from: http://www.ee.usp.br/doc/manual_de_enfermagem.pdf

11. Oliveira SRGP, Wendhausen ALP. (Re)Significando a Educação em Saúde: dificuldades e possibilidades da Estratégia Saúde da Família. Trab Educ Saúde [Internet]. 2014[cited 2016 Sep 15];12(1):129-47. Available from: http://www.scielo.br/pdf/tes/ v12n1/08.pdf

12. Sousa LB, Torres CA, Pinheiro PNC, Pinheiro AKB. Práticas de educação em saúde no Brasil: A atuação da enfermagem. Rev Enferm UERJ [Internet]. 2010[cited 2016 Sep 15];18(1):55-60. Available from: http://www.facenf.uerj.br/v18n1/v18n1a10.pdf

13. Albuquerque PC, Stotz EN. A educação popular na atenção básica à saúde no município: em busca da integralidade. Interface[Internet]. 2004[cited 2016 Sep 15];8(15):259-74. Available from: http://www.scielo.br/pdf/icse/v8n15/a06v8n15.pdf

14. Merhy EE. Saúde: a cartografia do trabalho vivo. 4a ed. São Paulo: HUCITEC; 2007.

15. Coscrato G, Bueno SMV. Concepção de enfermeiros de uma rede pública de saúde sobre Educação para a Saúde. Rev Esc Enferm USP[Internet]. 2013[cited 2016 Sep 15];47(3):714-21. Available from: http://www.scielo.br/pdf/reeusp/v47n3/en_0080-6234reeusp-47-3-00714.pdf

16. Guimarães GL. O perfil do enfermeiro-educador para o ensino de graduação. Esc Anna Nery Rev Enferm. 2005;9:255-60.

17. Merhy EE. Educação Permanente em Movimento - uma política de reconhecimento e cooperação, ativando os encontros do cotidiano no mundo do trabalho em saúde, questões para os gestores, trabalhadores e quem mais quiser se ver nisso. Saúde Redes [Internet]. 2015[cited 2016 Sep 15];1(1):7-14. Available from: http://revista.redeunida.org.br/ojs/index.php/rede-unida/ 
article/view/309

18. Rizio TA, Thomas WJ, O'Brien AP, Collins V, Holden CA. Engaging primary healthcare nurses in men's health education: a pilot study. Nurse Educ Pract [Internet]. 2016[cited 2016 Sep 15];17:128-33. Available from: http://dx.doi.org/10.1016/j. nepr.2015.11.011

19. Slomp Junior H, Feuerwerker LCM, Land MGP. Educação em saúde ou projeto terapêutico compartilhado? o cuidado extravasa a dimensão pedagógica. Cienc Saude Colet [Internet]. 2015[cited 2016 Sep 15];20(2):537-46.Available from: http://www.scielo.br/ pdf/csc/v20n2/en_1413-8123-csc-20-02-0537.pdf 